\title{
Additive apoptotic effect of STI571 with the cytoprotective agent amifostine in K-562 cell line
}

\begin{abstract}
Purpose: To study the apoptotic effect of the 2phenylaminopyrimidine derivative STI571 in combination with antioxidant agents on K-562 cell line derived from a Philadelphia chromosome-positive chronic myeloid leukemia patient. Materials and methods: K-562 $(\mathrm{BCR} / \mathrm{ABL}+)$, U-937, and HL60 (BCR/ABL-) leukemic cell lines were incubated with STI571 and the antioxidant agents catalase, glutathione, superoxide dismutase, and amifostine (AMI). Apoptotic effect was analyzed by morphological and flow cytometric criteria. Results: STI571 at concentrations higher than $0.25 \mu \mathrm{mol} \mathrm{L}{ }^{-1}$ produced apoptosis $(P<0.05)$ in $\mathrm{K}-562$ cells only after treatment for $72 \mathrm{~h}$. At the mentioned concentrations, STI571 also induced an increase in the loss of mitochondrial transmembrane potential from 24.6 to $40 \%$. Combination of STI571 $\left(0.5 \mu \mathrm{mol} \mathrm{L}{ }^{-1}\right)$ with antioxidant agents showed that the cytoprotective agent AMI $\left(0.75 \mathrm{mg} \mathrm{mL}^{-1}\right)$ produced an additive effect in the proapoptotic activity of STI571 in K-562 cells at nuclear $(58.8 \% \pm 2.0$ vs. $28.9 \% \pm 3.3)$ and mitochondrial $(53.3 \% \pm 3.6$ vs. $29.5 \% \pm 1.2)$ levels. Conclusions: Our results show that only AMI in combination with STI571, at submicromolar concentration, has an additive effect in K-562 cell line, and it does not have severe toxic effects on Philadelphia chromosome negative cells.
\end{abstract}

Keywords STI571 $\cdot$ Apoptosi $\cdot$ K-562 cell line · Antioxidant agents $\cdot$ Amifostine $\cdot$ Cell proliferation

Abbreviations AlloBMT: Allogeneic bone-marrow transplantation - AMI: Amifostine $\cdot$ ATP: Adenosine triphosphate $\cdot \mathrm{BC}$ : Fatal blastic phase $\cdot \mathrm{BCR} / \mathrm{ABL}-$ :

L. Vellón · M. González-Cid · M. de C. Nebel · I. Larripa $(\bowtie)$ Depto de Genética, Instituto de Investigaciones Hematológicas "Mariano R. Castex", Academia de Medicina,

J.A. Pacheco de Melo 3081, 1425 Buenos Aires, Argentina

E-mail: ibl@hematologia.anm.edu.ar

Tel.: + 54-11-48058803

Fax: + 54-11-48039475
$\mathrm{BCR} / \mathrm{ABL}$ negative cells $\cdot \mathrm{BCR} / \mathrm{ABL}+: \mathrm{BCR} / \mathrm{ABL}$ positive cells $\cdot \mathrm{CA}$ : Continuous administration $\cdot \mathrm{CAT}$ : Catalase $\cdot$ CML: Chronic myeloid leukemia $\cdot \mathrm{CP}$ : Chronic phase $\cdot \Delta \Psi_{\mathrm{m}}$ : Mitochondrial transmembrane potential - DMSO: Dimethyl sulfoxide - EDTA: Ethylenediaminetetraacetic acid · GSH: Glutathione - HDC: Highly damaged cells - IFN: Interferon - LMA: Low-melting agarose - MDC: Middle damaged cells PBS: Phosphate-buffer solution - PI-3k: Phosphatidylinositol-3 kinase - PMN: Polymorphonuclear cells - Rh123: Rhodamine 123 - RNAse A: Ribonuclease A - ROS: Reactive oxygen species - SOD: Superoxide dismutase - STI571: 2-Phenyaminopyrimidine derivative · UC: Undamaged cells

\section{Introduction}

Chronic myeloid leukemia (CML) is a clonal myeloproliferative disorder resulting from neoplastic transformation of the primitive hematopoietic stem cell [1]. The cytogenetic hallmark of CML is a reciprocal translocation between chromosomes 9 and 22 t $(9 ; 22)$ (q34;q11) [2]. This translocation results in a BCR/ABL hybrid gene and the fusion protein, $\mathrm{p} 210^{\mathrm{BCR} / \mathrm{ABL}}$. This protein has abnormal tyrosine kinase activity compared with normal c-ABL protein [3] and there is evidence that $\mathrm{p} 210^{\mathrm{BCR} / \mathrm{ABL}}$ itself can act as an antiapoptotic factor $[4,5]$.

The course of CML involves progression from a chronic phase (CML-CP) to an accelerated phase with duration of $1-1.5$ years followed by a fatal blastic phase (CML-BC) [6, 7].

Current therapies for $\mathrm{CML}$ include allogeneic bone-marrow transplantation (AlloBMT) and drug regimens including interferon (IFN)-alpha. AlloBMT is associated with substantial morbidity and mortality and is limited to patients for whom a suitable donor is available. IFN-alpha prolongs overall survival but has 
serious adverse effects. Thus, the overall cure for CML is less than $20 \%$ [8].

STI571, a 2-phenyaminopyrimidine derivative $\left(\mathrm{C}_{30} \mathrm{H}_{35} \mathrm{~N}_{7} \mathrm{SO}_{4}\right)$, is a potent ABL tyrosine kinase inhibitor with which encouraging results have been obtained in phase I and II clinical trials [9-11]. However, $60 \%$ of patients with myeloid CML-BC and most of patients with lymphoid CML-BC eventually relapse [9], indicating there are leukemic cells that overcome the proapoptotic effect of STI571 and survive in the presence of pharmacological concentrations of the drug [12].

To increase the cytotoxic effects of STI571, combinations of this drug with commonly employed anti-leukemic agents were used and shown to exert increased effects against $\mathrm{BCR} / \mathrm{ABL}$ positive cells as compared with STI571 alone $[13,14]$. On the other hand, exogenous expression of $\mathrm{p} 210^{\mathrm{BCR} / \mathrm{ABL}}$ in $\mathrm{BA} / \mathrm{F} 3,32 \mathrm{Dcl} 3$, and $\mathrm{M} 07 \mathrm{e}$ hematopoietic cell lines results in an increase of reactive oxygen species (ROS) in comparison with their untransformed counterparts; this would enhance BCR/ ABL-mediated transformation events by inhibiting cell phosphatases [15].

Taking these data into account, the aim of this work was to study the proapoptotic effect of the combination of STI571 with antioxidant agents on the erythroblastic K562 cell line, which is derived from a Philadelphia chromosome-positive CML patient [16].

\section{Materials and methods}

\section{Cell cultures}

K-562, BCR/ABL + (ATCC, USA), U-937, and HL60, BCR/ABL - (kindly provided by Dr Mirta Giordano from the Instituto de Investigaciones Hematológicas, Argentina) cells were maintained in a $5 \% \mathrm{CO}_{2}$ atmosphere at $37^{\circ} \mathrm{C}$ in RPMI 1640 medium supplemented with $10 \%$ heat-inactivated $\left(30 \mathrm{~min}, 65^{\circ} \mathrm{C}\right)$ fetal bovine serum. Cells were used for the studies in passages 3-10 after thawing. Polymorphonuclear cells from peripheral blood from six normal donors (PMN) were isolated by centrifugation in Ficoll-Histopaque and further sedimentation in a dextran gradient.

\section{Drug treatments}

K-562, U-937, and HL60 cells were incubated for 24, 48, and $72 \mathrm{~h}$ in the presence of STI571 (Imatinib, Gleevec, Novartis, Basel, Switzerland), at concentrations ranging between 0 and $2.5 \mu \mathrm{mol} \mathrm{L}{ }^{-1}$. Antioxidant agents were used in the dose range reported in previous papers: [1719]. Catalase, CAT $200 \mathrm{U} \mathrm{mL}^{-1}$ (Sigma, St Louis, USA), glutathione, GSH, $100 \mu \mathrm{mol} \mathrm{L}{ }^{-1}$ and $1 \mathrm{mmol}$ $\mathrm{L}^{-1}$ (Sigma), superoxide dismutase, SOD, $200 \mu \mathrm{g} \mathrm{mL}^{-1}$ (Sigma), and amifostine, AMI, $0.75 \mathrm{mg} \mathrm{mL}^{-1}$ (Actifos, Laboratorios Filaxis, Argentina) were added 15-30 min before treatment with STI571 $\left(0.5 \mu \mathrm{mol} \mathrm{L}^{-1}\right)$ and were present throughout the culture time. In addition, AMI, $0.75 \mathrm{mg} \mathrm{mL}^{-1}$, was added for $15 \mathrm{~min}$ and removed from the medium before STI571 treatment. PMN cells were incubated with antioxidant agents and STI571 for $24 \mathrm{~h}$.

\section{Apoptosis assessment}

Apoptosis was assessed by fluorescence microscopy, after staining of the cells with a mixture of acridine orange $\left(100 \mu \mathrm{g} \mathrm{mL}^{-1}\right)$ and ethidium bromide $\left(100 \mu \mathrm{g} \mathrm{mL}^{-1}\right)$ in PBS. Loss of nuclear structure or fragmented nuclei were taken as indicative of apoptotic cells. Apoptosis were also detected by flow cytometry, using loss of mitochondrial transmembrane potential $\left(\Delta \Psi_{\mathrm{m}}\right)$ as a marker of apoptosis. Loss of $\Delta \Psi_{\mathrm{m}}$ was assessed by incubating the treated cells with $0.3 \mu \mathrm{g} \mathrm{mL}^{-1}$ rhodamine 123 (Rh123) for $15 \mathrm{~min}$. Cytometric analysis was performed with a FacScan flow cytometer (Becton Dickinson, San Diego, USA). Cell Quest software was used for data acquisition and analysis.

Single-cell gel electrophoresis assay (comet assay)

For detection of DNA damage and apoptosis, the comet assay was carried out under alkaline conditions. After treatment, cells $(10 \mu \mathrm{L})$ were mixed with $75 \mu \mathrm{L} 0.75 \%$ low-melting agarose (LMA), spread on a slide precoated with normal melting agarose $(0.75 \%)$, and a third layer of LMA was then applied. The microscope slides were placed in cold lysis solution $\left(2.5 \mathrm{~mol} \mathrm{~L}^{-1} \mathrm{NaCl}\right.$, $100 \mathrm{mmol} \mathrm{L}^{-1}$ EDTA, $10 \mathrm{mmol} \mathrm{L}^{-1}$ Tris $\mathrm{pH} 10,1 \%$ Triton X-100, 10\% DMSO) and kept at $4^{\circ} \mathrm{C}$ for at least $1 \mathrm{~h}$. Slides were then transferred to an electrophoresis box containing an alkaline solution at $\mathrm{pH} 13$ (300 mmol $\mathrm{L}^{-1} \mathrm{NaOH}, 1 \mathrm{mmol} \mathrm{L}^{-1}$ EDTA) and kept for $20 \mathrm{~min}$ unwinding time at $4^{\circ} \mathrm{C}$. A current of $30 \mathrm{~V}$ (250 mA) was applied for $25 \mathrm{~min}$. Slides were removed, neutralized with $0.4 \mathrm{~mol} \mathrm{~L}^{-1}$ Tris $\mathrm{pH} 7.5$ for $5 \mathrm{~min}$, and stained with $20 \mu \mathrm{L}$ ethidium bromide $\left(20 \mu \mathrm{g} \mathrm{mL}^{-1}\right)$.

Comets were evaluated with a fluorescence microscope. A total of 100 comets on each slide were scored visually as belonging to one of three classes according to tail fluorescence intensity, tail length, and nucleoid integrity, and classified as undamaged cells (UC), cells with an intermediate grade of DNA damage (MDC), and highly damaged cells (HDC).

Cell proliferation: tritiated thymidine $\left({ }^{3} \mathrm{H}\right.$-thymidine $)$ incorporation and cell-cycle studies

K-562 cells $\left(200 \times 10^{3}\right.$ per well) were seeded in $200 \mu \mathrm{L}$ culture medium and treated with STI571 at concentrations ranging from 0 to $2.5 \mu \mathrm{mol} \mathrm{L}^{-1}$ for $72 \mathrm{~h}$. Eighteen hours before finishing the incubation $20 \mu \mathrm{L}$ per well of a working solution of ${ }^{3} \mathrm{H}$-thymidine $\left(0.05 \mu \mathrm{Ci} \mathrm{mL} \mathrm{mL}^{-1}\right)$ was added and activity was detected with a $\beta$ counter. 
To assess DNA ploidy levels STI571-treated K-562 cells were fixed in ethanol $70 \%$, treated with RNAse A (0.2 $\mathrm{mg} \mathrm{mL}^{-1}$ for $\left.15-30 \mathrm{~min}\right)$, and resuspended in propidium iodide (20 $\mu \mathrm{g} \mathrm{mL}^{-1}$ in PBS). Cytometric analysis was performed with a FacScan flow cytometer (Becton Dickinson). Modfit software was run for data acquisition and analysis.

\section{Statistical analysis}

Differences between mean results from the different treatments were evaluated by applying the paired Student's $t$-test.

\section{Results}

\section{STI571-induced apoptosis}

K-562, U-937, and HL60 cells were treated with STI571 at the stated concentrations $(0,0.01,0.05,0.25$,
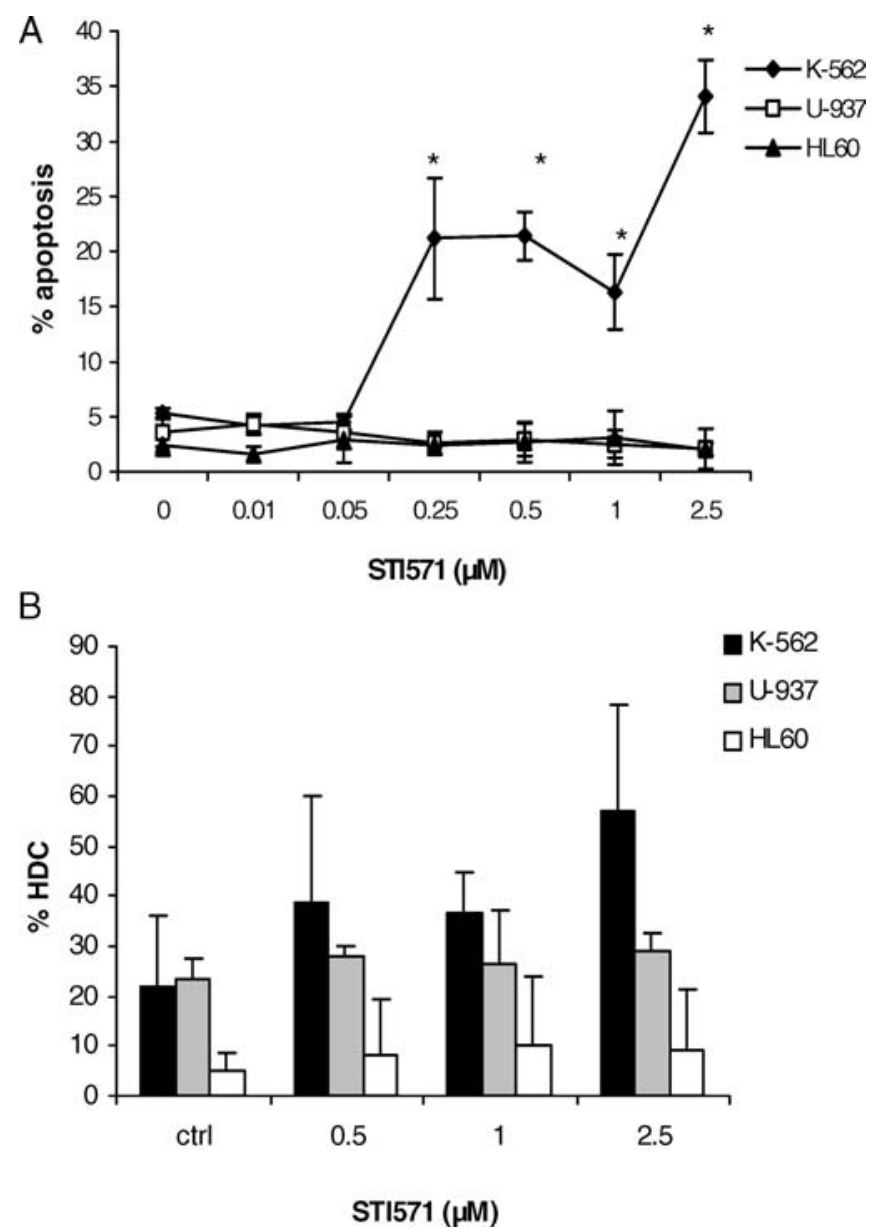

Fig. 1 A, STI571 (0-2.5 $\left.\mu \mathrm{mol} \mathrm{L}{ }^{-1}\right)$-induced apoptosis in K-562, U937, and HL60 cells after incubation for $72 \mathrm{~h}(* P<0.05)$. Representative of four independent experiments. B, Percentage of HDC (mean \pm SD) in K-562, U-937, and HL60 cell lines after incubation for $72 \mathrm{~h}$ with the indicated concentrations of STI571. Representative of three independent experiments
$0.5,1.0$ and $2.5 \mu \mathrm{mol} \mathrm{L}^{-1}$ ) for 24,48 , and $72 \mathrm{~h}$. Apoptosis was assessed by morphological analysis and only after $72 \mathrm{~h}$ of treatment; STI571 induced significant levels of apoptosis $(P<0.05)$ starting from $0.25 \mu \mathrm{mol} \mathrm{L}^{-1}$ in K-562 cells in comparison with untreated controls. No increase of apoptosis percentage was observed in STI571-treated U-937 and HL60 cell lines (Fig. 1A). The response of the leukemic cell lines to STI571 was also studied by the comet assay. A trend toward increased percentages of HDC in K-562 cells only after incubation with the drug for $72 \mathrm{~h}$ was observed, but no significant differences were found (Fig. 1B). STI571 at the mentioned concentrations also induced an increase in the loss of $\Delta \Psi_{\mathrm{m}}$ from 24.6 to $40 \%$ in $\mathrm{K}-562$ cells (Fig. 2).

\section{Cell-proliferation studies}

${ }^{3} \mathrm{H}$-Thymidine incorporation studies were performed with K-562 cells treated with STI571. It was found that after incubation with the drug for $72 \mathrm{~h}$ incorporation of ${ }^{3} \mathrm{H}$-thymidine decreased $(P<0.05)$ if concentrations of STI571 were higher than $0.25 \mu \mathrm{mol} \mathrm{L}{ }^{-1}$ (Fig. 3).

DNA content analysis by flow cytometry of K-562 cells in the presence of $\operatorname{STI} 571(0,0.5,1$, and $2.5 \mu \mathrm{mol} \mathrm{L}{ }^{-1}$ ) showed a lower percentage of cell subpopulations in $S$ and $G_{2} / M$ phases of cell cycle in comparison with untreated cells (Fig. 4)

\section{STI571 in combination with antioxidant agents}

To enhance the proapoptotic effect of STI571 in K-562 cells combined treatment with STI571 and antioxidant agents was studied. Cells were incubated for $30 \mathrm{~min}$ with
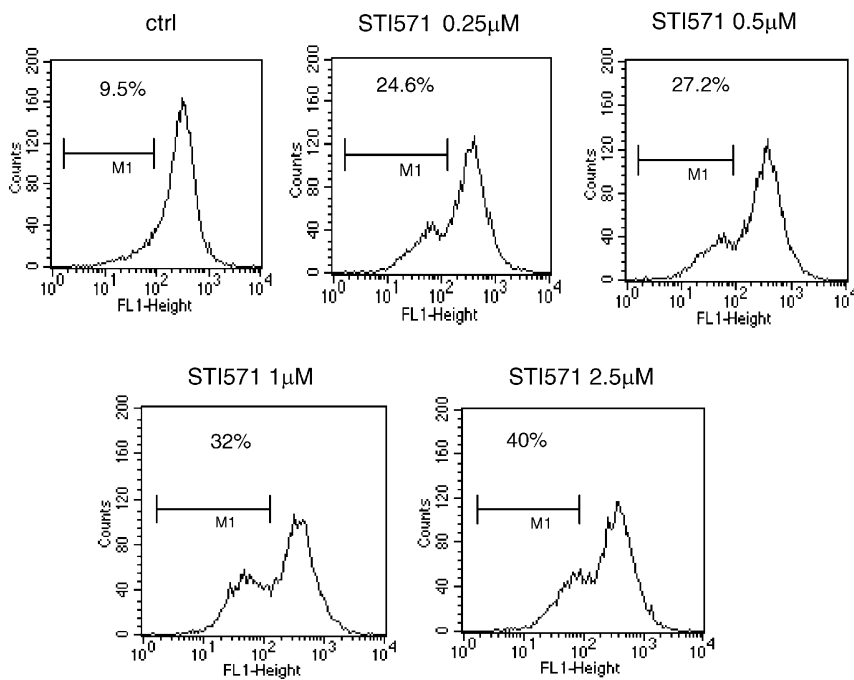

Fig. 2 Loss of $\Delta \Psi_{\mathrm{m}}$ in K-562 measured by Rh123 after incubation for $72 \mathrm{~h}$ with STI571 (representative of three independent experiments). M1: fraction of cells considered to have a decrease in their mitochondrial transmembrane potential, compared with untreated controls 


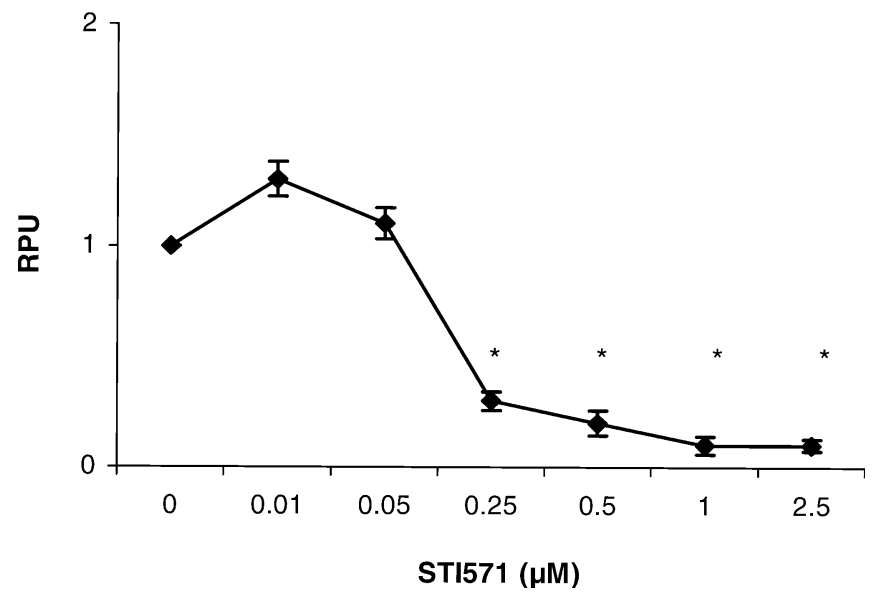

Fig. 3 Incorporation of ${ }^{3} \mathrm{H}$-thymidine by K-562 cells treated with STI571 for $72 \mathrm{~h}(* P<0.05$ in comparison with untreated control). ( $R P U$ relative proliferation units; referred to incorporation of ${ }^{3} \mathrm{H}$ thymidine in untreated cells as 1)

SOD, CAT, and GSH then the ABL tyrosine kinase inhibitor was added. Addition of these antioxidant agents did not modify the apoptotic value induced by STI571 alone (Fig. 5). Incubation with the cytoprotective agent AMI was carried out in two ways - continuous administration (CA) for $72 \mathrm{~h}$ and for $15 \mathrm{~min}$, after which it was removed from the culture medium before addition of STI571. Apoptosis was assessed by morphological and cytometric analysis, to study cell death at the nuclear and mitochondrial levels. By morphological detection the percentage of apoptosis induced by treatment with a combination of AMI for $15 \mathrm{~min}$ and STI571 (mean \pm SE, $28.7 \pm 3.3 \%$ ) was no different from that
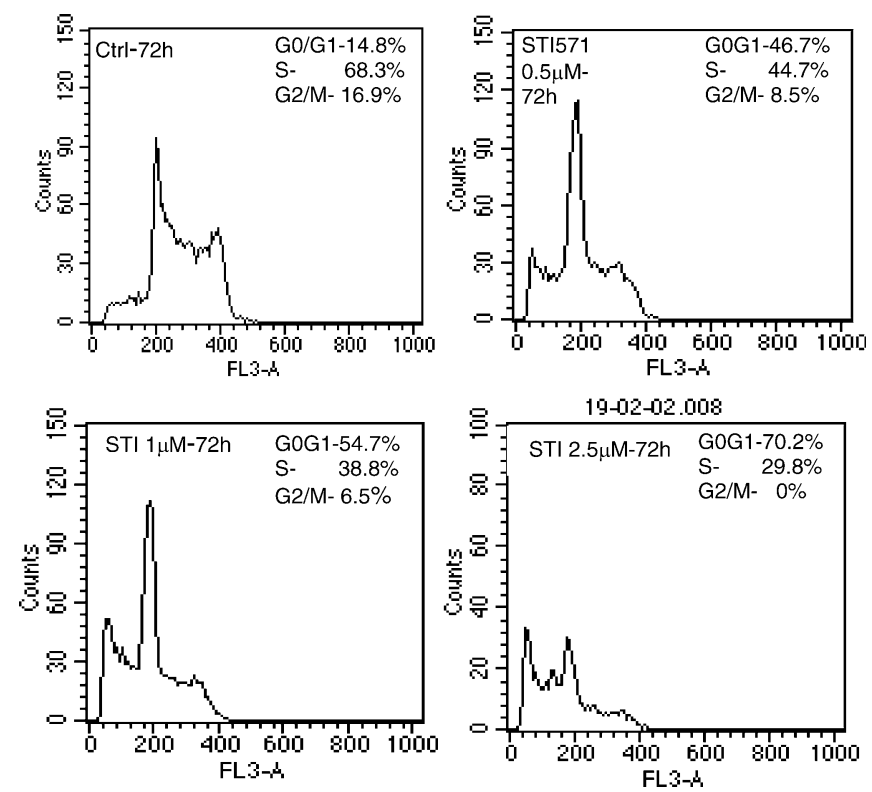

Fig. 4 DNA content histograms of K-562 cell line treated for $72 \mathrm{~h}$ with the indicated concentrations of STI571 (representative of three independent experiments). The apoptotic fraction was not considered in the cell cycle analysis resulting from treatment with STI571 alone (mean \pm SE, $28.9 \pm 4.0 \%)$. CA of AMI had an additive effect in combination with STI571 (mean \pm SE, $58.8 \% \pm 2.0$ ). This additive effect of STI571 and AMI (CA) was also observed at the mitochondrial level (mean $\pm \mathrm{SE}$, $53.3 \% \pm 3.6$ vs. $29.5 \% \pm 1.2$ in STI571-treated cultures) (Fig. 6).

To determine the specificity of the additive effect of STI571 and AMI in BCR/ABL + cells, U-937 cells (BCR/ABL - cells) were incubated with both drugs for $72 \mathrm{~h}$. By morphological detection of apoptosis it was observed that AMI was a strong apoptotic inducer in U937 cells; however, combination with STI571 did not increase levels of apoptosis (Fig. 7).

PMN cells from six normal donors were also treated with both drugs, taking into consideration that severe neutropenia is one of the most frequent adverse effects associated with treatment with STI571. This drug at $0.5 \mu \mathrm{mol} \mathrm{L}{ }^{-1}$ induced an increase of apoptosis and the effect was reversed by pretreatment with AMI after incubation for $24 \mathrm{~h}$ (Fig. 8).

These data indicate that AMI increased the apoptotic effect of STI571 and is specific for BCR/ABL + cells.

\section{Discussion}

Because the structure of several protein kinases has been determined, it is possible to design compounds based on the structure of the ATP binding site or their active site. One of these compounds, the 2-phenylaminopyrimidine derivative STI571, is a specific inhibitor of the ABL family of tyrosine kinases $\left(\mathrm{p} 210^{\mathrm{BCR} / \mathrm{ABL}}, \mathrm{p} 185^{\mathrm{BCR} / \mathrm{ABL}}\right.$, $\mathrm{v}-\mathrm{ABL}$, and c-ABL), although it also inhibits the kinase activity of platelet-derived growth factor receptor (PDGFR) and c-kit [20].

To study the antileukemic effect of STI571, K-562, U937, and HL60 leukemic cell lines were treated with concentrations of the drug up to $2.5 \mu \mathrm{mol} \mathrm{L}-1$.

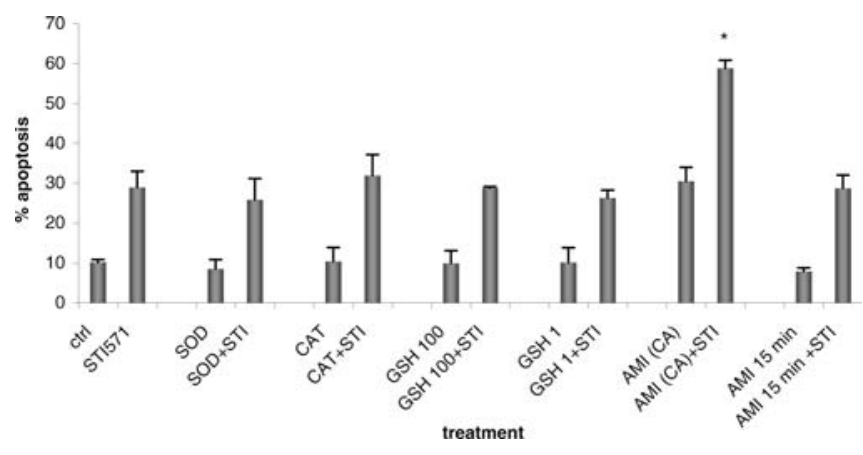

Fig. 5 Apoptosis, detected by morphological analysis (mean $\pm \mathrm{SE}$ ), induced in K-562 cells by STI571 $\left(0.5 \mu \mathrm{mol} \mathrm{L}^{-1}\right)$ in combination with antioxidant agents after incubation for $72 \mathrm{~h}$ (CAT catalase; SOD superoxide dismutase; GSH 100 glutathione $100 \mu \mathrm{mol} \mathrm{L}^{-1}$;

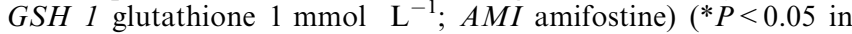
comparison with cells treated with STI571). Representative of five independent experiments 


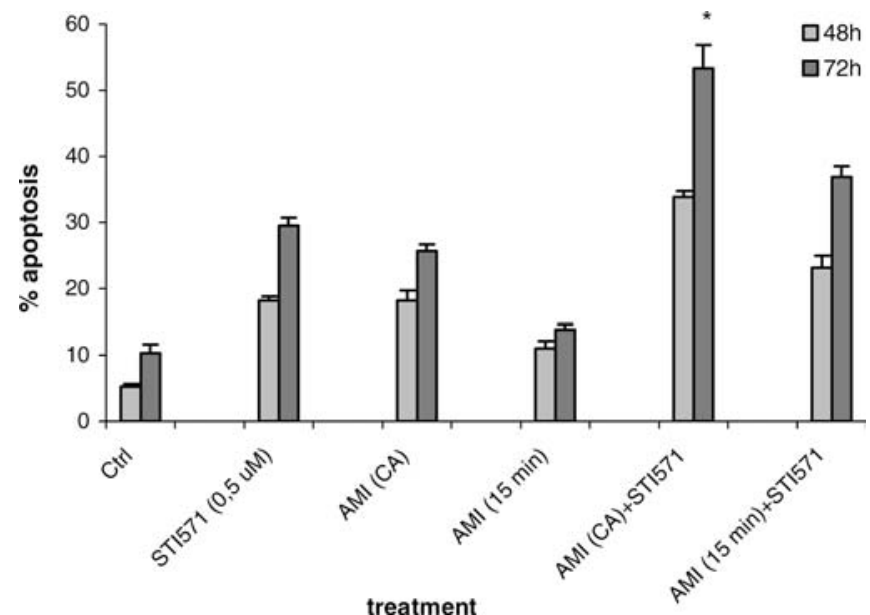

Fig. 6 Apoptosis (mean \pm SE) induced by STI571 $\left(0.5 \mu \mathrm{mol} \mathrm{L}^{-1}\right)$ in combination with AMI in K-562 cell line after incubation for 48 and $72 \mathrm{~h}$. Percentages represent loss of $\Delta \Psi_{\mathrm{m}}$ detected as a decrease in Rh123 fluorescence $\left({ }^{*} P<0.05\right.$ in comparison with cells treated with STI571). Representative of three independent experiments

STI571 induced significant levels of apoptosis in K562 cells after incubation for $72 \mathrm{~h}$ with the drug at concentrations higher than $0.25 \mu \mathrm{mol} \mathrm{L}{ }^{-1}$. U-937 and HL60 cells did not trigger apoptosis in response to STI571 after treatment for $72 \mathrm{~h}$ at the same concentrations. These data confirm previous reports showing induction of apoptosis in BCR/ABL transfected cell lines; while STI571 did not affect the viability of their wild-type counterparts [21].

Concentrations of STI571 employed were equivalent to those found in plasma from CML patients $24 \mathrm{~h}$ after administration of $400 \mathrm{mg}$ of the drug $\left(1.46 \mu \mathrm{mol} \mathrm{L}^{-1}\right)$ [9].

When apoptosis was measured at the mitochondrial level, Tabrizi et al. [14] reported that STI571 at $1 \mu \mathrm{mol} \mathrm{L}{ }^{-1}$ during $18 \mathrm{~h}$ of incubation was able to induce 10 to $40 \%$ apoptosis in four BCR/ABL-expressing cell lines-AR230, LAMA84, K562, and KCL22. This percentage was comparable with that obtained by us in K-562 cells.

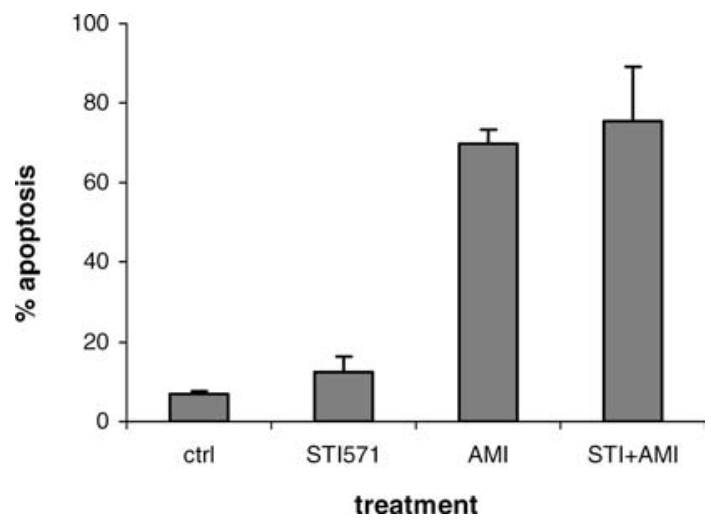

Fig. 7 Apoptosis (mean \pm SE) induced by STI571 $\left(0.5 \mu \mathrm{mol} \mathrm{L}{ }^{-1}\right)$ plus AMI in U-937 cells. Representative of three independent experiments

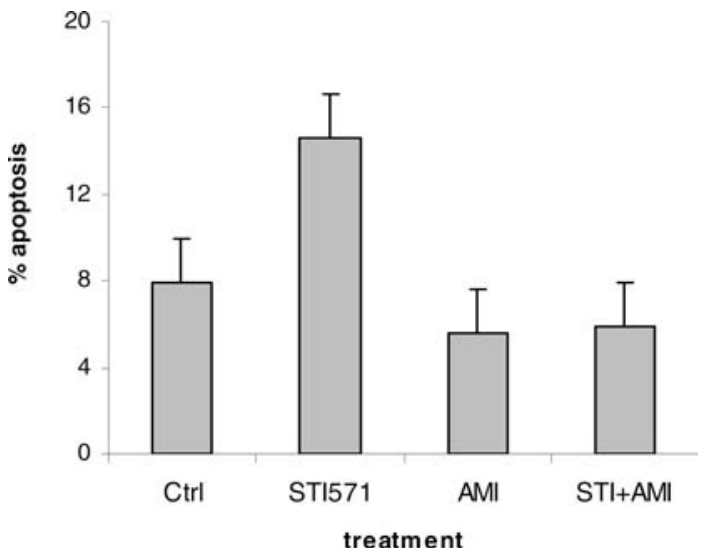

Fig. 8 Effect of STI571 $\left(0.5 \mu \mathrm{mol} \mathrm{L}{ }^{-1}\right)$ plus AMI on PMN cells from the peripheral blood of six healthy donors. Apoptosis (mean $\pm \mathrm{SE}$ ) was determined by morphological observation after $24 \mathrm{~h}$

Apoptotic response of the leukemic cell lines to STI571 was also analyzed by the comet assay; an increase in the percentage of highly damaged K-562 cells was observed after incubation with the drug for $72 \mathrm{~h}$. Such an increase was not observed for U-937 and HL60 cells.

Moreover, STI571 markedly decreased incorporation of ${ }^{3} \mathrm{H}$-thymidine in K-562 cells after incubation for $72 \mathrm{~h}$ with up to $2.5 \mu \mathrm{mol} \mathrm{L}^{-1}$ of the drug. DNA content analysis by flow cytometry showed a decrease in $\mathrm{S}$ and $\mathrm{G}_{2} / \mathrm{M}$ subpopulations in STI571-treated cells. Consistent with our results, Gambacorti-Passerini et al. [22] have shown that STI571-treatment induced a decrease in cycling cell lines derived from BCR-ABL + leukemias.

STI571 has given encouraging results in clinical trials on patients with CP-CML [9], with CP-CML refractory to IFN-alpha [10], and in those with the accelerated phase of CML. However, $60 \%$ of CML myeloid blast crisis and most lymphoid blast crisis eventually relapse [9] indicating there are cells which are able to grow continuously in the presence of STI571. Mechanisms of resistance to this drug vary between the different $\mathrm{BCR} /$ $\mathrm{ABL}+$ cell lines. The most frequent of these mechanisms, detected in BaF3 murine leukemic cells transformed with the BCR/ABL hybrid gene and in the human CML cell lines LAMA84 and AR230 is overexpression of the $\mathrm{BCR} / \mathrm{ABL}$ protein. Resistance to STI571 without an increase of $\mathrm{p} 210^{\mathrm{BCR} / \mathrm{ABL}}$ levels in subpopulations of K-562 and KCL22 cells has, however, been reported [12]. It has been shown in studies with cells from CML patients that resistance to STI571 was because of mutation (8/11 patients) or amplification of the BCR/ABL gene (3/11 patients) [23].

To improve the efficacy of treatment of Philadelphia chromosome-positive leukemias with STI571 there have been many studies of combination of STI571 with commonly used antileukemic agents, for example $\gamma$-irradiation, busulfan, treosulfan [13], and daunorubicin [14]. Combination of STI571 with the phosphatidylinositol-3 kinase (PI-3k) inhibitors, wortmannin and 
LY294002 has also been studied, because PI-3k activity is essential for the growth of Philadelphia chromosomepositive cells [8].

It has, on the other hand, been reported that transformation of BA/F3, 32Dcl3 and MO7e cell lines with $\mathrm{BCR} / \mathrm{ABL}$ gene results in an increase of ROS compared with their untransformed counterparts. This would enhance $\mathrm{p} 210^{\mathrm{BCR} / \mathrm{ABL}}$-mediated phosphorylation events, by ROS-mediated inhibition of cell phosphatases. This increase in ROS was because of $\mathrm{p} 210^{\mathrm{BCR} / \mathrm{ABL}}$ activity, because it was blocked by STI571 [15].

In this work the effect of combining STI571 with antioxidant agents on the leukemic cell lines K-562 and U-937 and on PMN from peripheral blood of normal donors has been evaluated. The concentration of STI571 used for the combination treatment was $0.5 \mu \mathrm{mol} \mathrm{L}{ }^{-1}$, almost one-third of the average concentration $\left(1.46 \mu \mathrm{mol} \mathrm{L}^{-1}\right)$ reached in the plasma of CML patients $24 \mathrm{~h}$ after administration of $400 \mathrm{mg}$ of the ABL kinase inhibitor [9]. The antioxidant agents used were SOD, CAT, GSH, and the cytoprotective agent AMI. Among these, AMI was the only one with an additive effect on the proapoptotic activity of STI571 in K-562 cell line at both nuclear and mitochondrial levels. This effect was not observed in U-937 cells or in PMN. AMI, a phosphorylated aminothiol prodrug, is dephosphorylated by membrane-bound alkaline phosphatases, releasing the active metabolite WR-1065, which quickly accumulates in normal tissues [24].

Continuous administration of AMI to p53-deficient cells K-562 and U937 induced an increase in the percentage of apoptotic cells, but this increase was not observed for the p53-proficient cells PMN. These data are in agreement with Lee et al. [25] who identify p53 protein as a mechanism of resistance to AMI-induced apoptosis.

AMI protects bone marrow progenitor cells from the cytotoxic effect of chemotherapeutic agents [26]. Clinical trials have shown that AMI reduces myelosupression resulting from irradiation, alkylating agents, and platinum analogs, while keeping their antitumor activity [27]. It has also been shown that this aminothiol exerts a protective effect on early and late hematological progenitor cells from the cytotoxic effects of cyclophosphamide derivatives [28]. All these data obtained in vitro support the use of AMI in association with chemotherapeutic agents to reduce toxicity in normal cells.

Our results show that AMI in combination with STI571 at submicromolar concentrations has an additive effect on the K-562 cell line whereas it does not have severe toxic effects on Philadelphia chromosome negative cells or normal PMN. The cytoprotective effect of AMI observed in PMN is very important, taking into account that severe neutropenia is one of the most frequent adverse effects associated with STI571 treatment. $[10,29]$. Similarly, Blasiak et al. [30] reported that AMI reduced the extent of DNA damage induced by the chemotherapeutic agent idarubicin in normal human lymphocytes and murine $\mathrm{BaF} 3$ cells, but when $\mathrm{BaF} 3$ cells were transformed with TEL/ABL gene, AMI potentiated the DNA-damaging effect of idarubicin.

Future studies should be performed to clarify whether the additive effect of using AMI in combination with STI571 in BCR/ABL + and p53- cells is related to the scavenger ROS properties and/or the proapoptotic activity of AMI on them. It should also be determined whether this combination of agents could be clinically relevant.

Acknowledgments This paper was supported by grants from CONICET, ANPCyT, and Academia Nacional de Medicina.

\section{References}

1. Cortes JE, Talpaz M, Kantarjian H (1996) Chronic myelogenous leukemia: a review. Am J Med 100:555-570

2. Rowley JD (1973) A new consistent chromosomal abnormality in chronic myelogenous leukemia identified by quinacrine fluorescence and Giemsa staining. Nature 243:290-293

3. Rosti V, Bergamaschi G, Ponchio L, Cazzola M (1992) c-Abl function in normal and chronic myelogenous leukemia hematopoiesis: in vitro studies with antisense oligomers. Leukemia 6:1-7

4. Evans C, Owen-Lynch P, Whetton AD, Dive C (1993) Activation of the Abelson tyrosine kinase activity is associated with suppression of apoptosis in hemopoietic cells. Cancer Res 53:1735-1738

5. Bedi A, Barber JP, Bedi GC, El-Deiry WS, Sidransky D, Vala MS, Akhtar AJ, Hilton J, Jones RJ (1995) BCL-ABL-mediated inhibition of apoptosis with delay of $\mathrm{G} 2 / \mathrm{M}$ transition after DNA damage: a mechanism of resistance to multiple anticancer agents. Blood 86:1148-1158

6. Faderl S, Talpaz M, Estrov Z, O'Brien S, Kurzrock R, Kantarjian HM (1999) The biology of chronic myeloid leukemia. N Engl J Med 341:164-172

7. Sawyers CL (1999) Chronic myeloid leukemia. N Engl J Med 340:1330-1340

8. Klejman A, Rushen L, Morrione A, Slupianek A, Skorki T (2002) Phosphatidylinositol-3 kinase inhibitors enhance the antileukemia effect of STI571. Oncogene 21:5868-5876

9. Druker BJ, Talpaz M, Resta DJ, Peng B, Buchdunger F, Ford JM, Lydon NB, Kantarjian H, Capdeville R, Ohno-Jones S, Sawyers CL (2001a) Efficacy and safety of a specific inhibitor of the BCR/ABL tyrosine kinase in chronic myeloid leukaemia. $\mathrm{N}$ Engl J Med 344:1031-1037

10. Druker BJ, Sawyers CL, Kantarjian H, Resta D, Fernandes Reese RNS, Ford JM, Capdeville R, Talpaz M (2001b) Activity of a specific inhibitor of the BCR/ABL tyrosine kinase in the blast crisis of chronic myeloid leukemia and acute lymphoblastic leukemia with the Philadelphia chromosome. N Engl J Med 344:1038-1042

11. Kantarjian H, Sawyers C, Hochhaus A, Guilhot F, Schiffer C, Gambacorti-Passerini C, Niederwieser D, Resta D, Capdeville R, Zoellner U, Talpaz M, Druker B (2002) Hematologic and cytogenetic responses to imatinib mesylate in chronic myelogenous leukemia. N Engl J Med 346:645-652

12. Mahon FX, Deininger MW, Schultheis B, Chabrol J, Reiffers J, Goldman JM, Melo JV (2000) Selection and characterization of BCR-ABL positive cell lines with differential sensitivity to the tyrosine kinase inhibitor STI571: diverse mechanisms of resistance. Blood 96:1070-1079

13. Topaly J, Fruehauf S, Ho AD, Zeller WJ (2002) Rationale for combination therapy of chronic myelogenous leukaemia with imatinib and irradiation or alkylating agents: implications for pretransplant conditioning. Br J Cancer 86:1487-1493 
14. Tabrizi R, Mahon FX, Cony Makhoul P, Lagarde V, Lacombe F, Berthaud P, Melo JV, Reiffers J, Belloc F (2002) Resistance to daunorubicin-induced apoptosis is not completely reversed in CML blast cells by STI571. Leukemia 16:1154-1159

15. Sattler M, Verma S, Shrinkhande G, Byrne CH, Pride YB, Winkler T, Greenfield EA, Salgia R, Griffin JD (2000) The $\mathrm{BCR} / \mathrm{ABL}$ tyrosine kinase induces production of reactive oxygen species in hematopoietic cells. J Biol Chem 275:24732478

16. Lozzio CB, Lozzio BB (1975) Human chronic myelogenous leukemia cell line with positive Philadelphia chromosome. Blood 45:321-334

17. Sato EF, Higashino M, Ikeda K, Wake R, Matsuo M, Utsumi $\mathrm{K}$, Inoue M (2003) Oxidative stress-induced cell death of human oral neutrophils. Am J Physiol Cell Physiol 284:1048-1053

18. Romano M, Lamberti A, Bisogni R, Garbi C, Pagnano A, Auletta P, Tassone P, Turco M, Venuta S (1999) Amifostine inhibits hematopoietic cell apoptosis by activating NF- $\kappa \mathrm{B} / \mathrm{Rel}$ transcription factors. Blood 94:4060-4066

19. Buschini A, Alessandrini Ch, Martino A, Pasini L, Rizzoli V, Carlo-Stella C, Poli P, Rossi C (2002) Bleomycin genotoxicity and amifostine (WR-2721) cell protection in normal leukocytes vs. K562 tumoral cells. Biochemical Pharmacology 63:967-975

20. Druker BJ (2003) Chronic myeloid leukemia in the imatinib era. Semin Hematol 40:1-3

21. Oetzel C, Jonuleit T, Götz A, van der Kuip H, Michels H, Duyster J, Hallek M, Aulitzky WE (2000) The tyrosine kinase inhibitor CGP 57148 (STI 571) induces apoptosis in BCRABL-positive cells by down-regulating BCL-X ${ }^{1}$. Clin Cancer Res 6:1958-1968

22. Gambacorti-Passerini C, le Coutre P, Mologni L, Fanelli M, Bertazzoli C, Marchesi E, Di Nicola M, Biondi A, Corneo GM, Belotti D, Pogliani E, Lidon NB (1997) Inhibition of the ABL kinase activity blocks the proliferation of $\mathrm{BCR} / \mathrm{ABL}+$ leukemic cells and induces apoptosis. Blood Cells Mol Dis 23:380394

23. Gorre ME, Mohammed M, Ellwood K, Hsu N, Paquette R, Nagesh Rao P, Sawyers CL (2001) Clinical resistance to STI571 cancer therapy caused by $\mathrm{BCR} / \mathrm{ABL}$ gene mutation or amplification. Science 293:876-880

24. Capizzi R (1996) Amifostine: the preclinical basis for broadspectrum selective cytoprotection of normal tissues from cytotoxic therapies. Semin Oncol 4:2-17

25. Lee EJ, Gerhold M, Palmer MW, Christen RD (2003) p53 protein regulates the effects of amifostine on apoptosis, cell cycle progression, and cytoprotection. Br J Cancer 88:754-759

26. Shaw LM, Bonner H, Lieberman R (1996) Pharmacokinetic profile of amifostine. Semin Oncol 23 (Suppl 8):18-22

27. Poloni A, Leoni P, Curzi L, Cantori I, Mancini S, Montanari M, Masia MC, Olivieri A (1999) Ex vivo purging of leukapheresis collections with nitrogen mustard: amifostine pretreatment improves both early and late pheripheral blood progenitor cell recovery. Exp Hematol 27:1548-1556

28. Douay L, Hu C, Giarratana M-C, Gorin N-C (1995) Amifostine (WR-2721) protects normal haematopoietic stem cells against cyclophosphamide derivatives' toxicity without compromising their antileukaemic effects. Eur J Cancer 31a (Suppl 1): s14-s16

29. Sneed TB, Kantarjian HM, Talpaz M, O'Brien S, Rios MB, Bekele BN, Zhou X, Resta D, Wierda W, Faderl S, Giles F, Cortes JE (2004) The significance of myelosuppression during therapy with imatinib mesylate in patients with chronic myelogenous leukemia in chronic phase. Cancer100:116-121

30. Blasiak J, Gloc E, Mlynarski W, Drzewoski J, Skórski T (2002) Amifostine differentially modulates DNA damage evoked by idarubicin in normal and leukemic cells. Leukemia Res 26:1093-1096 